International Journal of Linguistics, Literature and Translation

ISSN: 2617-0299 (Online); ISSN: 2708-0099 (Print)

DOI: $10.32996 / \mathrm{ijllt}$

Journal Homepage: www.al-kindipublisher.com/index.php/ijltt

IJLLT

\title{
Viewing Joe Biden's Victory Speech in 2020 from the Perspective of Language Metafunction
}

\author{
Lanlan Shi 8(D) \\ Faculty of English Language and Culture, Guangdong University of Foreign Studies, Guangzhou, China \\ $\triangle$ Corresponding Author: Lanlan Shi, E-mail: sll.1999@qq.com
}

\begin{tabular}{|c|c|}
\hline ARTICLE INFORMATION & ABSTRACT \\
\hline Received: June 10, 2021 & \multirow{7}{*}{$\begin{array}{l}\text { From the perspective of functional linguistics, this paper analyzes the features of the } \\
\text { discourse pattern of political speeches from the perspective of critical discourse } \\
\text { analysis, taking Biden's } 2020 \text { election victory speech as a model, and explores how } \\
\text { political speeches realize ideational functions in language through transitivity system, } \\
\text { voice system and normalization system, and how they realize interpersonal functions } \\
\text { through mood system and modality system, how to realize textual function through } \\
\text { theme-rheme structure, information structure, and cohesion system. A political } \\
\text { speaker's mastery of his own subjective and objective attitude, the shaping of the } \\
\text { credibility and persuasiveness of his speech, the construction of one's own social } \\
\text { identity, interpersonal relationship, and ideology can be embodied through the three } \\
\text { meta-functions of language. }\end{array}$} \\
\hline Accepted: July 21, 2021 & \\
\hline Volume: 4 & \\
\hline Issue: 7 & \\
\hline DOI: 10.32996/ijllt.2021.4.7.12 & \\
\hline KEYWORDS & \\
\hline $\begin{array}{l}\text { Political speech; critical discourse } \\
\text { analysis; functional grammar; } \\
\text { metafunction }\end{array}$ & \\
\hline
\end{tabular}

\section{Introduction}

The concept of speech refers to a specific space-time environment, with the means of sound language and the corresponding body language, to openly convey information to the audience, express views, explain things, and to express feelings, to reach the goal of appealing to the audience. It is an artistic social practice, a means of imparting knowledge, and a powerful tool of social communication, among which political speech is a kind of speech type widely concerned. Its speakers mainly expound and comment on important events and realistic problems both at home and abroad from the political angle. Election speeches, inaugural speeches, reports on the work of governments at all levels, meetings and debates, speeches at political gatherings, diplomatic speeches, military speeches, political and ideological education and so on all belong to the category of political speeches. Often we can learn from political speeches about the social culture, traditional customs, historical background, and ideology of the speaker and even the country he or she represents. TV debates of American presidential candidates and presidential inaugural speeches are good learning materials for English learners and are well-loved by Chinese English learners, take, for example, President Biden's speech on the night of the 2020 election victory. It was a passionate and impactful speech, a classic, both in its words and in Biden's performance. There is no denying that, despite his statesmanship, Biden is a veritable oratorical genius. Biden used the function of language appropriately in this speech, establishing a positive political and social image among the audience, making his political aspirations widely accepted and rallying voters of all classes and levels, fully demonstrated his vision as a politician and future national leader.

In recent years, functional grammar has become a commonly used analytical method in critical discourse analysis. Halliday, the founder of functional grammar, believes that the ideational, interpersonal, and textual functions of human language constitute the three major meta-functions of adult language. The three meta-functions of language exist simultaneously in adult language because the speaker is always communicating with others through coherent discourse (discourse function), reflect the objective world around you and your inner world (concept function). The choice is meaning. Text is the result of choosing from the whole language system under the influence of various social factors and the communicative purposes of language participants. Each clause in the text constructs the social meaning of political identity, interpersonal relationship, and ideology by choosing the specific grammatical and semantic embodiment of the three meta-functions. Therefore, this paper will use the three meta-

K C AL-KINDI CENTER

$\mathbf{R}$ DFOR RESEARCH AND DEVELOPMENT

Your gateway to world-class research

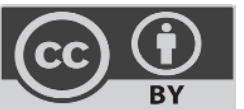

Published by Al-Kindi Center for Research and Development, London, United Kingdom. Copyright (c) the author(s). This open access article is distributed under a Creative Commons Attribution (CC-BY) 4.0 license 
functions of language to analyze Biden's 2020 election victory speech, with a view to exploring the linguistic features of political speech as a discourse pattern and the law of constructing the deep social meaning behind its linguistic form.

\section{Ideational function}

According to Halliday, ideational function refers to the function of language to express people's experiences in the external world and the inner world. The ideational function is often embodied by the transitivity system, the voice system, and the unitary system of the clause.

\section{i. Transitivity}

Transitivity is a semantic system that expresses the functions of concepts. Its function is to divide people's experiences in the external and inner worlds into several "Processes". The basic framework of the various processes in the transitivity system is very simple, in addition to the "Process" itself, there are "Participants" and "Environment". In a clause, "Process" is represented by a verb, "Participant" by a noun, and "Environment" by an adverb or prepositional phrase. There are six "Processes" in the transitivity system. A process is a process of doing something, an action, or an event that takes place. It generally has two participants "The actor" and "The goal", which are respectively the logical subject and the object of the material process. The most common material process clause is: The Mayo R solved The committee. The psychological process can be said to be a "Feeling" process, indicating psychological activities. It generally has two participants: the subject of mental activity, the perceiver, and the object, the perceived phenomenon. The most common mental process clauses are: I believe you. The process of relationship is the process of expressing "Yes", which reflects the relationship between things. This process can be divided into "Modified" and "Identity", the former refers to a certain entity that has what attributes, the latter refers to an entity and another entity is unified. For example, Sarah is WIse and Tom is the leader. 4 behavioral processes are used to represent physical and psychological behaviors, such as breathing, coughing, laughing, crying, dreaming, staring, sighing, etc. . There is usually only one actor in the process of behavior, that is, "Actor". The most common course of action clause is: He is sleeping. 5 the process of speech is the process of "Telling", and "Telling" generally refers to the exchange of information. This process often has only one participant -- the "Speaker" -followed by the verbs say, Tell, talk, praise, toast, describe, and so on. The most common speech process clauses are: My Watch says it's half-past ten. The process of being is the process of expressing the existence or occurrence of things. There must be a "Being" in every existential clause, and common verbs such as be, exist, remain, arise, happen, take place, come about, etc. The most common existential clause is: There's a patient to see you. These six processes summarize the most important activities and events in the world of human experience.

Biden's 2020 election victory speech has a total of sentences, six processes appear in the text. There were 117 physical processes, accounting for $49.16 \%$ of the total. There were 51 relational processes, accounting for $21.43 \%$ of the total. The frequency of material processes and relational processes is the highest, accounting for $70.59 \%$ of the total. In addition, mental processes occurred 31 times, accounting for $13.03 \%$ of the total. The behavior process occurred 16 times, accounting for $6.72 \%$ of the total process. The process of existence and the process of speech occur only 14 times and 9 times, respectively, accounting for $5.88 \%$ and $3.78 \%$ of the total process. The choice of process type is of cultural, political, and ideological importance. The political orientation of the speaker determines the choice of process type. Biden's 2020 victory speech could be described as a speech of thanks for the victory, a statement of objective facts and values, a speech of persuasion on governing policies, and a call for unity and cooperation among the people and political parties. From the analysis of the conceptual function of the text, the following conclusions can be drawn.

(1) the part of acknowledgments and the part of appeals in the text mainly choose the psychological and behavioral processes. The psychological process expresses emotion, cognition, and feeling, with distinct subjective consciousness. Biden fully expresses his gratitude to voters, supporters, and running mates through the psychological process. Biden used this process to call on people to be hopeful and act decisively in the face of a new epidemic in the United States.

E. g.

(1) And I believe that this is part of the mandate from the American people.

(2) We must make the promise of the country real for everybody

(3) And if we can decide not to cooperate, then we can decide to cooperate.

(4) And I call on the Congress - Democrats and Republicans alike - to make that choice with me.

(5)I will name a group of leading scientists and experts as Transition Advisors to help take the Biden-Harris COVID plan and convert it into an action blueprint that starts on January 20th, 2021. 
"Believe" in sentence 1 is a mental process, "Make" in sentence 2, "Decide" in sentence 3, "Call on" in sentence 4, "Name" and "Help" in sentence 5 are behavioral processes, the process is applied in a way that shows Biden's gratitude to his constituents, supporters, and running mates in a way that is particularly human and intimate, bringing him closer to his audience, this, in turn, helped to spread the message of his policies and the importance of national unity. It helped to call on the people, Masatomo, and even his political enemies to take action and work together for the prosperity and strength of the country. Biden also expressed his feelings for the country and the people, Hope, the determination of governance, more show the words, take the lead.

(2) the narrative of Biden's help during the election and his future policies, as well as the explanation of objective facts and values, are mainly expressed through the material process. Generally speaking, a text will always be dominated by a material process. Because the physical world is primary. Human activity is the fundamental guarantee of human existence. The material process is mainly used to describe what happens in the outside world -- what has happened, what is going on, and what is going to happen. Therefore, the choice of material processes, in large measure, reflects the objectivity and authenticity of the speech, enhances its credibility and persuasiveness, convinces the audience of the correctness and feasibility of Biden's political program, and heeds his call. For example:

(1) We cannot repair the economy, restore our vitality, or relish life's most precious moments — hugging a grandchild, birthdays, weddings, graduations, all the moments that matter most to us - until we get this virus under control.

(2) Let this grim era of demonization in America begin to end - here and now.

(3) The refusal of Democrats and Republicans to cooperate with one another is not due to some mysterious force beyond our control.

(4) Ahead to an America that never gives up never gives in.

(3) the discourse description of objective facts and the explanation of values also chooses the process of relationship. The process of relationship indicates the relationship between things and reflects people's interpretation of objective things and their understanding of various relations.

For example:

(1) This is a great nation.

(2) And we are good people.

(3) And there has never been anything we haven't been able to do when we've done it TOGETHER.

(4) America is a beacon for the globe.

In his discourse, Biden illustrates the relations with his opponents, partners, family members, and the world, compares the political, economic, cultural, and racial situations in American history and at present, and analyzes the status of the American people in the past, present, and future as well as the internal and external relations of the American government. The proportion of the speech process in discourse is very small. Political speech must embody the objectivity, the material process, and the relational process in this respect is undoubtedly an ideal choice. A small amount of the speech process is used in the quotation because the speaker wants to gain the trust and support of the audience. Biden uses a famous quote from Johnson to add to his argument.

\section{ii. Voice system}

Based on functional grammar analysis, the function of voice is to indicate which participant a process first establishes contact with. Voice can be divided into middle voice and non-middle voice. If a process itself involves only one participant and no other participants, the process clause is in the middle voice. If a process involves two or more participants, the process clause is in the non-middle voice. The non-middle voice includes the active voice and the passive voice. The active voice refers to the relationship between a process and its author, while the passive voice refers to the relationship between a process and its object.

Almost all of Biden's 2020 victory speech was in the middle and active voice, and only the announcement of vice presidential candidate Harriss used both passive voices to emphasize the correctness of the decision, for Harriss, to the Biden campaign and all those who have worked so hard. But the passive voice is also used in contrast to the active voice: the United States has experienced rapid economic, cultural, and technological development, and is currently undergoing political and democratic changes, in the future, as long as all the people give full play to their subjective initiative, even more, drastic changes will be triggered. The goal is to rally the American people to confront the challenges of the new crown disease, the economic crisis, racism, and climate change. 


\section{iii. Polarity}

The ideational function of polarity is that it makes a certain proposition or proposal a negotiable concept, indicating that the proposition or

The proposal is positive or negative. The following sentence is taken from Biden's victory speech in 2020.

(1) It is the honor of my lifetime that so many millions of Americans have voted for this vision.

(2) The refusal of Democrats and Republicans to cooperate with one another is not due to some mysterious force beyond our control.

(3) America has always been shaped by inflection points - by moments in time where we've made hard decisions about who we are and what we want to be.

(4) Our nation is shaped by the constant battle between our better angels and our darkest impulses.

The function of this application is to emphasize the merits and demerits of past history, point out the right and wrong lines, establish a positive influence, and give positive guidance, so as to make a solemn commitment to how the government should govern in the future, and propose how the people should exercise their rights and perform their obligations. Feasible suggestions. It can be seen that the normalization system can also reflect the political identity, ideology, and national will of the speaker in political speeches.

\section{Interpersonal function}

Language also has the functions of expressing the speaker's identity, status, attitude, motivation, and inferences about things. This is the interpersonal function.

can. It is the function of the speaker to use language to participate in social activities. Through this function, the speaker engages himself in a certain situation

In the context of the scene, to express his attitude and inference, and to try to influence the attitude and behavior of others. Functional grammar divides the basic speech roles that people can recognize into two categories: giving and requesting. The speaker is not only doing things himself but also asking the listeners to do things. Therefore, discourse is not static, but an interactive and exchange process. Discourse is the exchange of information or goods and services. For the exchange of information, the text is a proposition. For the exchange of goods and services, the text is a suggestion. The grammar of interpersonal meaning is the grammar about the exchanges between the two parties in a conversation, which is often reflected in the tone system and modality system.

\section{i. Tone system}

The mood system (mood) is a lexical and grammatical system that expresses interpersonal functions, including two parts-the subject and the limiting component.

The subject in the tone system can also be understood as the subject structure in traditional grammar. The choice of subject in the text can also reflect the speaker's

Ideology mainly depends on the speaker's social status, communicative intentions, and understanding and views of social reality. Biden

The subject of each clause in the 2020 election victory speech is mostly "we". Americans have always been individual supreme and advocating liberalism. Therefore, the application of first-person plural pronouns in the text can emphasize unity and arouse a collective consciousness, weaken the differences within the group, and then arouse American national pride and responsibility. Make the speech more provocative and appealing. Such as:

(1) We must restore the soul of America.

(2) We have the opportunity to defeat despair and to build a nation of prosperity and purpose.

(3) We stand again at an inflection point.

(4) We must make the promise of the country real for everybody - no matter their race, ethnicity, their faith, their identity, or their disability.

(5)And we are a good people. 
The first-person singular pronoun "I" as the subject appears 36 times in the text. The application of "I" makes the audience feel cordial and impressed by Biden's sincere and honest, personal and courteous personality charm. Such as:

(1)And I hope it can provide some comfort and solace to the more than 230,000 families who have lost a loved one to this terrible virus this year.

(2)I've always believed we can define America in one word: Possibilities.

(3) In the last days of the campaign, I've been thinking about a hymn that means a lot to me and to my family, particularly my deceased son Beau.

\section{ii. Modal system}

Modality is the main semantic carrier of interpersonal function, which covers the domain of meaning between the two polarities of normalization. Reflected in the proposition, it includes possibility and generality, called modalization, which can usually be expressed through modal auxiliary verbs or modal modifiers expressing possibility and generality. Reflected in suggestions, it includes responsibility and inclination, which is called modulation, which can usually be expressed through modal auxiliary verbs and some passive predicative components or predictive components that express requirements and suggestions. The modal system indicates the speaker's assessment of the authenticity of the proposition, the attitude of the responsibility and obligation it bears, and it can also define the social distance and power relationship between the speaker and the listener.

In political speeches, speakers often use modality to convey their implicit ideology and political intentions. In Biden's 2020 election victory speech, almost all modalities were expressed through modal verbs, accounting for $20.58 \%$ of the total number of qualified elements, and mentality was also expressed through modal verbs, accounting for $1.28 \%$ of the total number of qualified elements. Biden expresses his judgments on domestic and international affairs that have occurred or is happening to the public through modalities. His statements are mainly to persuade and appeal to the audience. Therefore, he uses "will", "can", "may" and other low-value modal verbs to create a friendly atmosphere to shorten the distance between the audience and encourage the audience to take action. The application of mentality uses the high-value modal verb "must" to emphasize the severe situation facing the United States. It is not only the responsibility of the US president and government to strive for change, but also the unshirkable responsibility of every American citizen. Everyone must be full of hope And confidence to deal with the crisis. It is worth mentioning that the phenomenon of modal metaphor appears in this discourse. The speaker used "I know" and "I"Think" replaces modal verbs to express modalities.

\section{Textual function}

The ideational and interpersonal functions of a text are ultimately expressed through language, so they are bound to be restricted by language features.

Related to text function. In the semantic layer, the function of organizing language components into text is called the text function. According to Halliday, discourse function includes three subsystems-thematic structure, information structure, and cohesive system. The thematic structure includes theme and rheme: theme is the starting point of the sentence and the starting point of communication content, and the components other than theme are rheme. Information structure refers to the order of appearance of new information and known information in clauses. Research on human cognition has found that unmarked themes (i.e. the phenomenon of subject and theme overlap) and the information structure of new information after known information is easier to make the logical and semantic coherence of the text, which helps listeners to understand the information. Receiving and understanding make it easier to achieve the function of informing and persuading.

Marked themes rarely appear in Biden's 2020 election victory speech, and the word order of most clauses is normal. This is because Biden, as the new president, and his speechwriter fully prepared, after repeated careful scrutiny, fully considered the audience's language acceptance ability and wrote the speech, so the speech reflects the integrity, coherence, and logic of the written text Sex. But generally speaking, political speeches have commonalities between written and spoken texts. Biden's speeches delivered on the spot through television broadcasts were extremely infectious and possessed the flexibility of oral language. The following two sentences are excellent examples:

(1) With full hearts and steady hands, with faith in America and in each other, with a love of country - and a thirst for justice let us be the nation that we know we can be.

(2) And now, together - on eagle's wings - we embark on the work that God and history have called upon us to do.

Biden's 2020 election victory speech has many common forms of cohesion such as reference, substitution, and connection, but the theme and rheme progression mode and information structure of the text also play a very coherent role in the text, that is, repeat the previous one. The theme of the sentence and the known information. 
Such as:

A nation united.

A nation strengthened.

A nation healed.

\section{Conclusion}

After two defeats in the election, Biden has accumulated a lot of experience. Therefore, in his victory speech, he will strive to establish a positive image and good prestige, win the hearts of the people, eliminate excessive racial divisions, and promote the unity of the nation, political parties, and classes. In order to achieve this goal, Biden has fully explored language functions. In the ideational function, material process and relationship process, middle voice and active voice, and affirmative normalization are used to strengthen the objectivity and persuasiveness of speech. In the interpersonal function, the first-person subject is used to narrow the distance with the audience, the third-person subject is used to highlight one's political leadership, and a reasonable modality is used to reflect the national will. Strive for completeness and coherence of logic and semantics in discourse function. All these fully reflect the prominent features of the discourse model of political speech in the language function. But this paper considers mainly language metafunction due to the limits of publication. Future work can adopt other perspectives to enrich studies on public speeches.

\section{Reference}

[1] Fairclough, N. (1992). Discourse and Social Changes, Cambridge and New York: Polity Press.

[2] Fairclough, N. (1989). Language and Power, New York: Longman.

[3] Fowler, R. et al. (1979). Language and Control, London, Boston, and Henley: Routledge and Kegan Paul.

[4] Gee, J. (2005). An Introduction to Discourse Analysis: Theory and Method, 2nd ed. New York: Routledge.

[5] Halliday, M. (2004). An Introduction to Functional Grammar, London: Hodder Arnold.

[6] Kress, G and Robert H. (1979). Language as Ideology, London, Boston \& Henley: Routledge and Kegan Paul.

[7] Phillips, L. and Marianne J. (2002). Discourse Analysis as Theory and Method, London: SAGE Publications.

[8] Scollon, R and Suzanne S. "Lighting the Stove: Why habitus isn't enough for critical discourse analysis," In A New Agenda in (Critical) Discourse Analysis, edited by Ruth W and Paul C, 111-116.

[9] Scollon, S. (2003). Political and Somatic Alignment: habitus, ideology and social practice," In Critical Discourse Analysis. Theory and Interdisciplinarity, edited by Gilbert W and Ruth W, 169-174. London and N.Y.: Palgrave Macmillan. 